\title{
Type I caramel products of maltose and sucrose with water and their antioxidant activities
}

\author{
Tian-Xiao LI ${ }^{1,2,3}$ (D), Cheng LUO ${ }^{1}$, Zong-Ze GENG ${ }^{1}$, Zhong-Rong JIANG ${ }^{1}$, Ling-Bo JI', Hong-Qian SHENTU ${ }^{1}$, \\ Yun-Fei XIE ${ }^{3}$, Jun $\mathrm{HU}^{4}$, Yuan-Fa LIU ${ }^{3}$, Dong-Liang $\mathrm{LI}^{1^{*}}$ (D)
}

\begin{abstract}
To study the caramel reactions of disaccharides with water, the type I maltose caramel products (MCPs) and sucrose caramel products (SCPs) at three reaction stages were yielded and their reaction rates, UV absorptions, flavor compounds, and antioxidant activities were also detected. It was found that the caramel reactions of sucrose were faster than those of maltose and their reaction rates quickly increased to a high level in the middle stage. UV absorption of SCP in the late stage at $305 \mathrm{~nm}$ was much stronger than those of MCPs. Both the MCP and SCP obtained at $180^{\circ} \mathrm{C}$ and 4 min had the highest concentrations of 5-hydroxymethylfurfural and total flavor compounds. Moreover, the total flavor concentrations of SCPs were much larger than those of MCPs and the antioxidant effects of SCPs were also stronger. Thus, a preferred condition for both two disaccharide caramel reactions was suggested at $180^{\circ} \mathrm{C}$ for $4 \mathrm{~min}$ and the sucrose caramels could give better flavors than maltose caramels.
\end{abstract}

Keywords: caramel reactions; maltose; sucrose; flavor compounds; antioxidant activities.

Practical Application: Caramel manufacture, quality control, and caramel flavors.

\section{Introduction}

Caramel colors, one of the most widely used dietary additives, have been classified as four distinct types by their processing (Chappel \& Howell, 1992; Golon \& Kuhnert, 2012). With the participation of ammonia and ammonium salts, type III and type IV caramels can be manufactured through both Maillard and caramel reactions. However, some toxic and cancerogenic substances such as 4(5)-tetrahydroxybutylimidazole (THI) and 2-acetyl-4-methylimidazole (4-MEI) could also be yielded, which led to the limitation of their food use levels (Cunha et al., 2011; Klejdus et al., 2006; Moon \& Shibamoto, 2011). Type II caramels are only allowed for several special medicines and foods (Chappel \& Howell, 1992). In contrast, the plain caramels (type I) are more safe and promising.

The plain caramels could be yielded using sugars with water or sugars alone. Although the colors of these caramels are slightly weaker than other types, their flavors are more comfortable and natural. Several perfumed compounds like pyranones, furans, and furanones have been reported through heating waterless glucose and fructose (Geng et al., 2019; Golon \& Kuhnert, 2013; Pons et al., 1991). Under sugar-water system, the reactions could be controlled easily and accurately. It has been found that disaccharide caramels could give more rich flavors but their characteristic aromatic compounds under sugar-water system are not known clearly enough (Chappel \& Howell, 1992; Cunha et al., 2011). Moreover, the qualities and applications of caramels can be associated with their flavor compounds and biological activities. In this study, two kinds of disaccharides (maltose and sucrose) were chosen. Their caramel reactions with water were performed and the preferred processing conditions were established. The reaction rates, UV absorptions, and characteristic flavors of maltose caramel products (MCPs) and sucrose caramel products (SCPs) were confirmed, as well as the antioxidant effects.

\section{Materials and methods}

\subsection{General experimental procedures}

Maltose (99\%), sucrose (99\%), and trolox were obtained from Aladdin Reagent Co., Ltd (Shanghai, China). 2,2-Diphenyl-1picrylhydrazyl (DPPH), 2,2-azino-bis-3-ethylbenzothiazoline6-sulfonic acid (ABTS), and 5-hydroxymethylfurfural were purchased from Macklin Reagent (Shanghai, China). A DF-101S magnetic stirrer (Yuhua Co., Ltd, Zhengzhou, China) was used for the caramel reactions. UV and optical density (OD) data were acquired on UV-2450 equipment (Shimadzu, Tokyo, Japan) and iMark microplate reader (BIO-RAD, Contra Costa, USA), respectively. HPLC-ELSD analysis was carried on an Agilent 1290 HPLC equipped with a 385 ELSD detector (Agilent, Santa Clara, USA). GC-MS determination was carried out on an Agilent 8890GC/5977MSD (Agilent, Santa Clara, USA).

\subsection{Heating procedure}

In two $1000 \mathrm{~mL}$ of round-bottomed flasks, maltose $(200 \mathrm{~g})$ and sucrose $(200 \mathrm{~g})$ were transferred respectively. Then each of the flask was added with purified water $(100 \mathrm{~g})$ and heated in an oil bath of $187^{\circ} \mathrm{C}$ with a stirring speed of $1000 \mathrm{rpm}$ (Pons et al., 
1991). When the reacting temperature reached 140 (a), 170 (b), and $180^{\circ} \mathrm{C}(\mathbf{c})$, each of the MCPs and SCPs $(25 \mathrm{~g})$ were transferred at once. Caramel products $\mathbf{d}$ were obtained that the remaining mixtures were kept at $180^{\circ} \mathrm{C}$ for $4 \mathrm{~min}$. After being added with purified water (50\% weight), the residual caramels (d) were heated at $180{ }^{\circ} \mathrm{C}$ for another 2 min to give products e. All the caramel products were dissolved in $10 \%$ alcohol as the stock solutions $(1.0 \mathrm{~g} / \mathrm{mL})$.

\subsection{Reaction rate analysis}

Maltose and sucrose solutions ( $10 \%$ alcohol) were prepared in concentrations of 5.0, 2.0,1.0, 0.5 , and $0.1 \mathrm{mg} / \mathrm{mL}$, which were determined by HPLC-ELSD analysis. Then the standard curves were demonstrated. The MCP and SCP solutions were diluted with $10 \%$ alcohol to the concentration of $5.0 \mathrm{mg} / \mathrm{mL}$ and determined as above. Then the concentrations of maltose and sucrose in the MCP and SCP solutions and the reaction rates were calculated according to the standard curves and peak areas.

HPLC-ELSD analysis was carried out with an Agilent Pursuit 5 PFP column $(250 \mathrm{~mm} \times 4.6 \mathrm{~mm})$. The mobile phase was $5 \%$ $\mathrm{MeOH}$ with $0.1 \% \mathrm{HCOOH}$ with a flow rate of $1 \mathrm{~mL} / \mathrm{min}$ and the injection volume was $5.0 \mu \mathrm{L}$. For the ELSD detector, the gas carrier was $\mathrm{N}_{2}$ with a flow rate of $1.6 \mathrm{~L} / \mathrm{min}$, and the temperature of evaporator was set at $45^{\circ} \mathrm{C}$.

\subsection{UV and GC-MS analysis}

The UV data from 200 to $550 \mathrm{~nm}$ were collected using the water dilute solution of MCPs and SCPs $(2.0 \mathrm{mg} / \mathrm{mL})$.

In ten round-bottom flasks (100 mL), each of MCP and SCP solutions $(12 \mathrm{~mL}, 1.0 \mathrm{~g} / \mathrm{mL})$ was transferred and extracted using ultrasonic treatment with $\mathrm{CH}_{2} \mathrm{Cl}_{2}(10 \mathrm{~mL})$ for $2 \mathrm{~min}$. After being heated at $60^{\circ} \mathrm{C}$ for another 20 min under reflux, the $\mathrm{CH}_{2} \mathrm{Cl}_{2}$ layers were pipetted out to another bottle. The remaining solutions were extracted with $\mathrm{CH}_{2} \mathrm{Cl}_{2}$ in the same manner as aforementioned. Finally, the two $\mathrm{CH}_{2} \mathrm{Cl}_{2}$ layers were concentrated to $0.9 \mathrm{~mL}$ in

Table 1. The HPLC-ELSD peak areas of different maltose and sucrose solutions.

\begin{tabular}{ccc}
\hline $\begin{array}{c}\text { concentrations } \\
(\mathrm{mg} / \mathrm{mL})\end{array}$ & maltose & sucrose \\
\hline 0.1 & 112.6 & 123.5 \\
0.5 & 515.4 & 679.6 \\
1.0 & 1387.5 & 1501.2 \\
2.0 & 2281.2 & 2754.8 \\
5.0 & 5683.0 & 6504.3 \\
\hline
\end{tabular}

the fume hood and the internal standard 2-phenethyl propionate $(0.1 \mathrm{~mL}, 1.78 \mathrm{mg} / \mathrm{mL})$ was added.

GC-MS analysis was performed on an Agilent 8890GC/5977MSD with a HP-5 MS column $(60 \mathrm{~m} \times 0.25 \mathrm{~mm})$. The injection volume was $1.0 \mu \mathrm{L}$. The gas carrier was helium with flow rate of $1.0 \mathrm{~mL} / \mathrm{min}$ and column temperature was set as below: $50^{\circ} \mathrm{C}$, hold for $2 \mathrm{~min} ; 50^{\circ} \mathrm{C}$ to $120^{\circ} \mathrm{C}, 6^{\circ} \mathrm{C} / \mathrm{min} ; 120^{\circ} \mathrm{C}$ to $240{ }^{\circ} \mathrm{C}$, $12{ }^{\circ} \mathrm{C} / \mathrm{min}$, hold for $5 \mathrm{~min} ; 240{ }^{\circ} \mathrm{C}$ to $280{ }^{\circ} \mathrm{C}, 15^{\circ} \mathrm{C} / \mathrm{min}$, hold for $3 \mathrm{~min}$.

\subsection{Antioxidant assays}

Through ABTS and DPPH assays, the radical scavenging effects of MCPs and SCPs were tested (Li et al., 2020; Thomas and Bielski, 1989). Briefly, the ABTS solution and potassium persulfate solution were mixed equally and put in the dark for $18 \mathrm{~h}$. Using $50 \%$ ethyl alcohol, the mixture was diluted to $0.70 \pm 0.05\left(\mathrm{~A}_{734 \mathrm{~nm}}\right)$ and caramel product solutions $(50.0-0.5 \mathrm{mg} / \mathrm{mL})$ were also prepared. Then in the 96-well plates, each caramel product solution $(20 \mu \mathrm{L})$ was pipetted into $180 \mu \mathrm{L}$ of ABTS solutions. Finally, the OD values at $734 \mathrm{~nm}$ were measured after reacting avoiding light for 6 minutes. For the DPPH assays, $100 \mu \mathrm{L}$ of DPPH solutions $(0.25 \mathrm{mM})$ and equal volume of caramel product solutions were added. After reacting for 30 minutes, the OD values $\left(\mathrm{A}_{517 \mathrm{~nm}}\right)$ were recorded. All the measurements were carried out in triplicate. The scavenging rate was calculated as following: scavenging rate $(\%)=\left(1-A_{\text {test }} / A_{\text {control }}\right) \times 100$.

\section{Results and discussion}

\subsection{The reaction rates of MCPs and SCPs}

Maltose and sucrose solutions were prepared with $10 \%$ alcohol to concentrations of $5.0,2.0,1.0,0.5$, and $0.1 \mathrm{mg} / \mathrm{mL}$, which were further analyzed by HPLC-ELSD (Table 1). The standard curves were established by the peak areas and the concentrations (Figure 1). Then the MCP and SCP solutions were diluted with $10 \%$ alcohol to the concentration of $5.0 \mathrm{mg} / \mathrm{mL}$ and analyzed in the same manner (Figure 2). The reaction rates were calculated through the peak areas and the standard curves (Table 2).

Based on the reaction phenomena and the reaction rates, three reaction stages could be revealed, namely the early stage, the middle stage, and the late stage. From the reaction beginning to the arriving of $170^{\circ} \mathrm{C}(\mathbf{b})$ could be supposed as the early stage. It is interesting to note that the caramel reaction of sucrose was faster than those of maltose since the reaction rate of SCP $\mathbf{b}$ $(61.3 \%)$ was larger than those of maltose $(22.8 \%)$. The middle stage was defined as from arriving of $170^{\circ} \mathrm{C}(\mathbf{b})$ to $180^{\circ} \mathrm{C} 4 \mathrm{~min}$ (d) and the reaction rates quickly increased to $87.0 \%$ and $92.3 \%$

Table 2. The reaction rates of different MCPs and SCPs.

\begin{tabular}{|c|c|c|c|c|c|c|}
\hline \multirow{2}{*}{ products } & \multicolumn{3}{|c|}{ maltose } & \multicolumn{3}{|c|}{ sucrose } \\
\hline & peak area & concentration & reaction rate $(\%)$ & peak area & concentration & reaction rate $(\%)$ \\
\hline a & 5249.0 & 4.60 & 8.0 & 5328.4 & 4.05 & 18.9 \\
\hline b & 4411.6 & 3.86 & 22.8 & 2588.8 & 1.93 & 61.3 \\
\hline c & 2117.4 & 1.83 & 63.4 & 1281.9 & 0.92 & 81.5 \\
\hline d & 789.8 & 0.65 & 87.0 & 585.6 & 0.38 & 92.3 \\
\hline e & 225.2 & 0.15 & 97.0 & 117.6 & 0.02 & 99.6 \\
\hline
\end{tabular}


for maltose and sucrose, respectively. In this stage, the sugars were reacting drastically to become dilated foams, which were finally broken and cooled down at around $4 \min \left(180^{\circ} \mathrm{C}\right)$. The following $\mathbf{d}$ to $\mathbf{e}$ were regarded as the late stage and the reaction rates were in the stable levels.

\subsection{UV absorptions of MCPs and SCPs}

Along with the reaction, it was found that the UV absorptions from 200 to $550 \mathrm{~nm}$ were significantly enhanced and two peaks (305 and 290 nm) were discovered (Figure 3) (Uríčková \& Sádecká,
2015). In the early stage, the UV absorptions at $290 \mathrm{~nm}$ and $305 \mathrm{~nm}$ were slightly increased. In the middle stage, $\mathrm{UV}_{290 \mathrm{~nm}}$ was quickly enhanced to the stable level and $\mathrm{UV}_{305 \mathrm{~nm}}$ also obviously increased. It has been known that the sugars were first polymerized before decomposition into flavor compounds in the caramel reactions and the UV absorptions at $290 \mathrm{~nm}$ could be associated with the polymerized sugars (Chappel \& Howell, 1992; Golon \& Kuhnert, 2013). As mentioned above, the sucrose could react faster than maltose since the UV absorptions at $290 \mathrm{~nm}$ of SCP b was larger than those of MCP b (Figure 3). In the late stage, it was found that sucrose caramel exhibited a much darker color
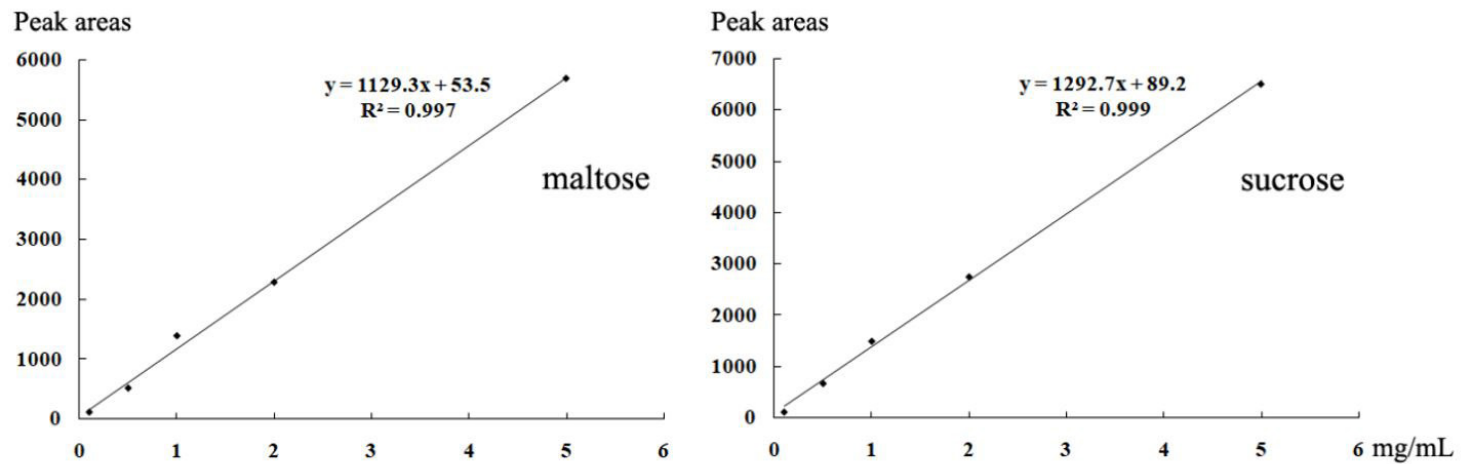

Figure 1. HPLC-ELSD standard curves of maltose and sucrose.
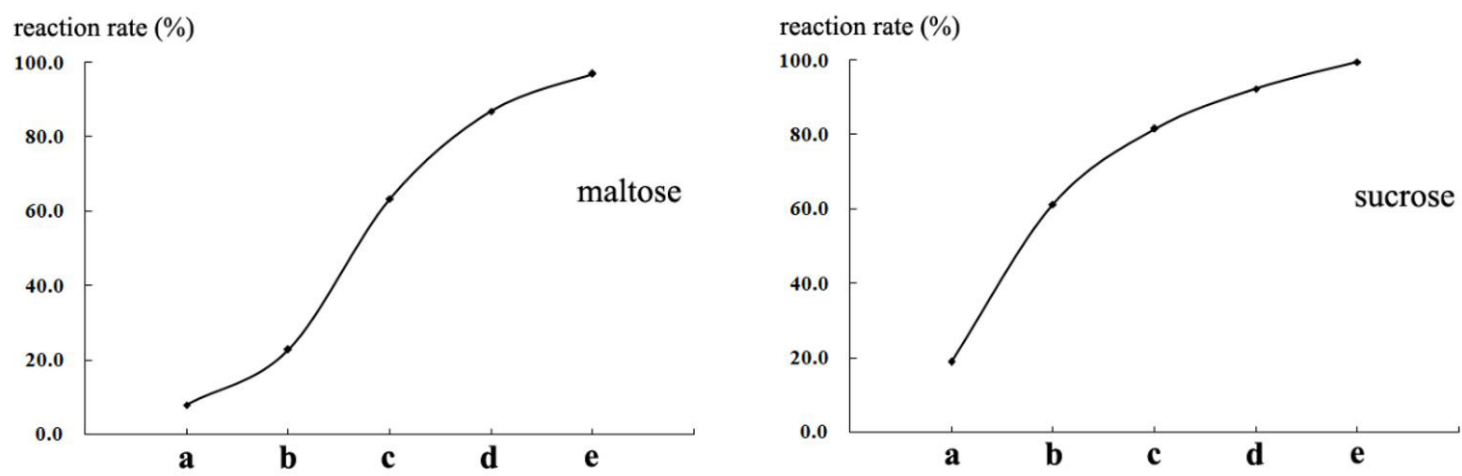

Figure 2. The reaction rate curves of MCPs and SCPs. (a) $140{ }^{\circ} \mathrm{C}, 0 \mathrm{~min}$; (b) $170{ }^{\circ} \mathrm{C}, 0 \mathrm{~min}$; (c) $180^{\circ} \mathrm{C}, 0 \mathrm{~min} ;(\mathbf{d}) 180^{\circ} \mathrm{C}, 4 \mathrm{~min} ;(\mathbf{e}) 180^{\circ} \mathrm{C}, 4 \mathrm{~min}$, $50 \%$ water supplement, reacted at $180^{\circ} \mathrm{C}$ for another $2 \mathrm{~min}$. The same below.
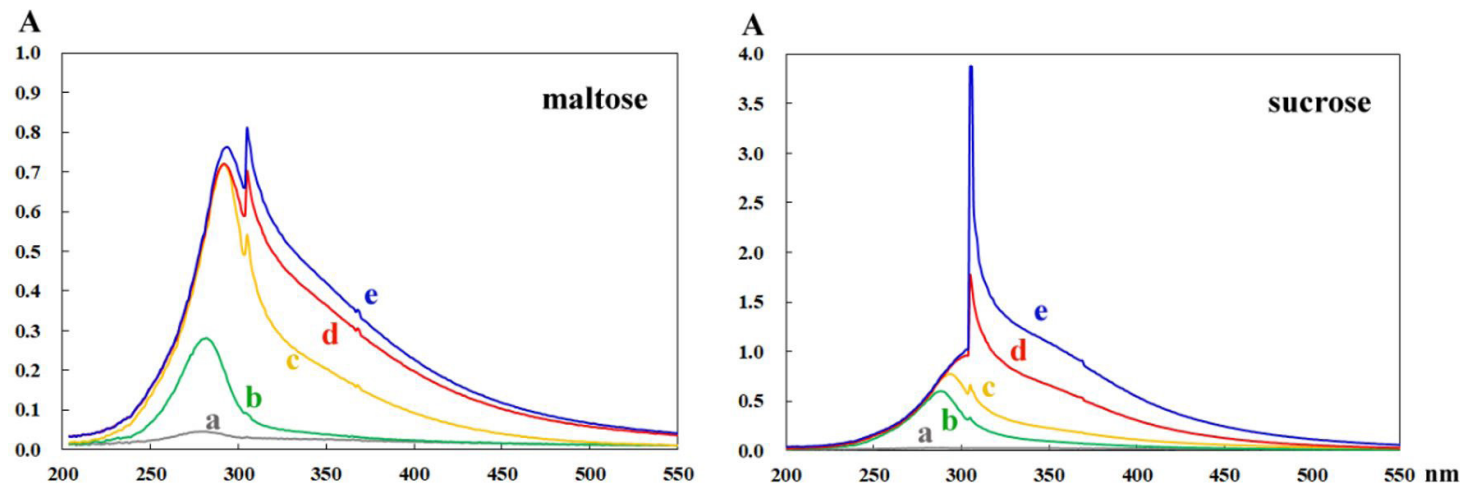

Figure 3. UV absorptions of MCPs and SCPs in water (A, absorbance). 
than maltose caramel since the UV absorption at $305 \mathrm{~nm}$ of SCP e was much larger than those of MCP e (Figure 4).

\subsection{Flavor compounds of MCPs and SCPs}

Careful analysis of the GC-MS data of MCPs and SCPs revealed 18 flavor compounds that can be distinguished as three classes (Table 3 and Figure 5) (Golon \& Kuhnert, 2013; Pons et al., 1991). 4-MEI and THI were not detected. Class I was the flavor compounds that found in both MCPs and SCPs, namely the compounds 1-7. Among them, 5-hydroxymethylfurfural (5-HMF, 1), methyl-2-furoate (2), furfural (3), 2,3-dihydro-3,5-dihydroxy-6-methyl-4H-pyran4-one (DDMP, 4), and 1-(2-furanyl)-ethanone (5) could be recognized as the main flavor compounds since they were found in both middle and late stage products. In addition, compounds 8-11 (class II) were the flavors that only yielded in MCPs and the remaining 12-18 (class III) were only observed in SCPs.

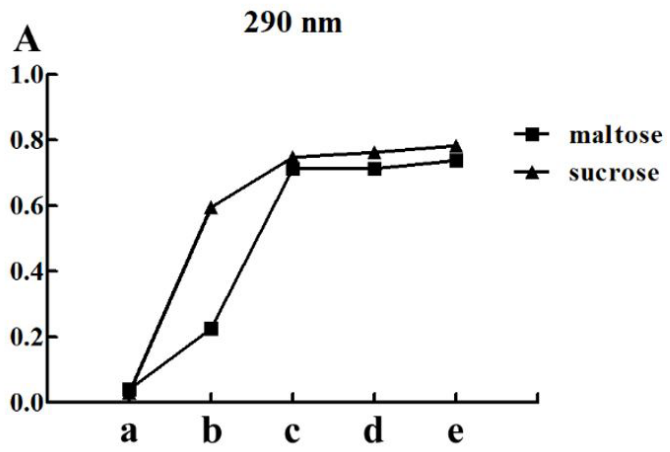

Among MCPs, it is interestingly to note that product $\mathbf{d}$ was disclosed to have highest concentration values of 5-HMF and total flavor compounds (Table 3 and Figure 6). For SCPs, the same result could also be observed although the number of flavor compounds in $\mathbf{e}$ was larger than those of $\mathbf{d}$. Thus, a proposed condition for both maltose and sucrose caramel reactions was established at $180^{\circ} \mathrm{C}$ for $4 \mathrm{~min}$. In this condition, the total flavor concentration of SCP $\mathbf{d}$ was eight fold more than those of MCP (Table 3), which suggested that sucrose caramels could give better flavors than maltose caramels.

\subsection{Antioxidant effects}

Along with the caramel reactions, the antioxidant effects of MCPs and SCPs were fast enhanced, which reached the stable levels at the late stages with $\mathrm{IC}_{50}$ values decreased to 0.93 and $0.44 \mathrm{mg} / \mathrm{mL}$ for MCP and 0.45 and $0.24 \mathrm{mg} / \mathrm{mL}$ for SCP, respectively (Table 4 and Figure 7). It has been reported that DDMP exhibited ABTS and DPPH radical scavenging effects due

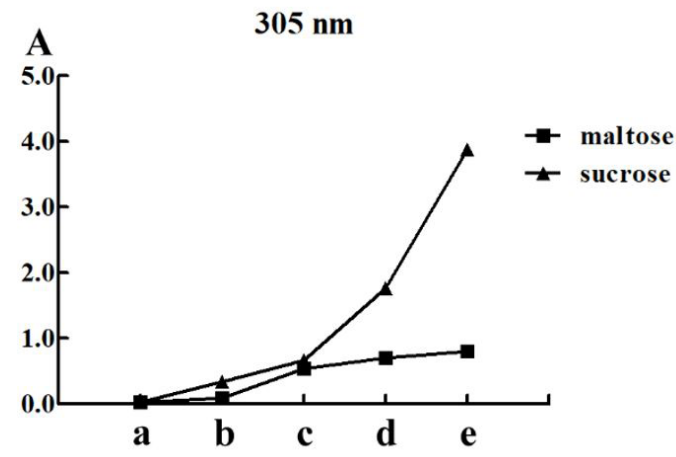

Figure 4. UV absorptions of MCPs and SCPs at 290 and $305 \mathrm{~nm}$ (A, absorbance).

Table 3. Concentrations of the flavor compounds in MCPs and SCPs $(\mu \mathrm{g} / \mathrm{mL})$.

\begin{tabular}{|c|c|c|c|c|c|c|c|c|c|c|c|}
\hline \multirow{2}{*}{ No. } & \multirow{2}{*}{ flavor compounds } & \multicolumn{5}{|c|}{ maltose } & \multicolumn{5}{|c|}{ sucrose } \\
\hline & & $\mathbf{a}$ & $\mathbf{b}$ & c & d & e & a & $\mathbf{b}$ & c & d & e \\
\hline 1 & 5-hydroxymethylfurfural & $-^{\star}$ & 48.21 & 67.47 & 86.78 & 41.11 & - & 142.46 & 398.74 & 673.45 & 512.60 \\
\hline 2 & methyl-2-furoate & - & 0.54 & 0.71 & 1.22 & 1.14 & - & 2.33 & 10.57 & 27.96 & 33.61 \\
\hline 4 & 2,3-dihydro-3,5-dihydroxy-6-methyl-4H-pyran-4-one & - & 0.54 & 1.58 & 1.82 & 0.74 & - & 2.90 & 4.83 & 12.36 & 14.66 \\
\hline 5 & 1-(2-furanyl)-ethanone & - & 0.28 & 0.56 & 1.27 & 1.79 & - & - & 0.69 & 0.72 & 0.75 \\
\hline 8 & 2-furanmethanol & - & - & 0.09 & 0.44 & 0.59 & - & - & - & - & - \\
\hline 9 & 3-methyl-2-furoic acid & - & - & 0.11 & 0.04 & - & - & - & - & - & - \\
\hline 10 & 2-acetyl-5-methylfuran & - & - & 0.04 & - & - & - & - & - & - & - \\
\hline 11 & 3,4-furandimethanol & - & - & - & 0.03 & - & - & - & - & - & - \\
\hline 12 & 5-methyl-2(5H)-furanone & - & - & - & - & - & - & - & - & 1.28 & 2.59 \\
\hline 17 & 5-(2-furanylmethyl)-2-furancarboxaldehyde & - & - & - & - & - & - & - & - & - & 3.55 \\
\hline \multirow[t]{2}{*}{18} & 5-[(5-methyl-2-furanyl)methyl]-2-furancarboxaldehyde & - & - & - & - & - & - & - & - & - & 3.34 \\
\hline & 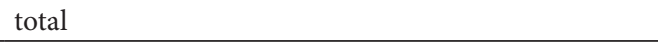 & - & 49.57 & 72.18 & 92.61 & 46.08 & - & 155.66 & 450.02 & 762.48 & 631.25 \\
\hline
\end{tabular}

${ }^{*}$, not detected. 
to the olefinic alcohol group in its structure (Yoshiki \& Okubo, 1995; Yu et al., 2013). Thus, the stronger antioxidant effects of SCPs were associated with their higher concentrations of DDMP than those of MCPs (Figure 6). Also, since the concentration of DDMP in MCP e was decreased, its radical scavenging effects were reduced (Figures 6 and 7).

Table 4. $\mathrm{IC}_{50}$ values of MCPs and SCPs in the antioxidant assays $(\mathrm{mg} / \mathrm{mL})$.

\begin{tabular}{cccccc}
\hline \multirow{2}{*}{ products } & \multicolumn{2}{c}{ maltose } & & \multicolumn{2}{c}{ sucrose } \\
\cline { 2 - 3 } \cline { 5 - 6 } D & DPPH & ABTS & DPPH & $13.62 \pm 1.73$ & ABTS \\
\hline $\mathbf{b}$ & $16.95 \pm 1.88$ & $3.74 \pm 0.93$ & & $9.43 \pm 0.72$ & $0.86 \pm 0.92$ \\
$\mathbf{c}$ & $6.28 \pm 0.93$ & $0.66 \pm 0.14$ & $2.26 \pm 0.19$ & $0.50 \pm 0.08$ \\
$\mathbf{d}$ & $2.20 \pm 0.36$ & $0.41 \pm 0.07$ & $0.47 \pm 0.06$ & $0.25 \pm 0.08$ \\
$\mathbf{e}$ & $0.84 \pm 0.07$ & $0.44 \pm 0.09$ & $0.45 \pm 0.04$ & $0.24 \pm 0.07$ \\
5 -HMF & $0.93 \pm 0.06$ & $>2.00$ & $>2.00$ & $>2.00$ \\
Trolox $^{*}$ & $>2.00$ & $0.04 \pm 0.01$ & $0.04 \pm 0.01$ & $0.04 \pm 0.01$ \\
\hline
\end{tabular}

${ }^{*}$ Positive control. Maltose and sucrose were considered as inactive since its $\mathrm{IC}_{50}>50.0 \mathrm{mg} / \mathrm{mL}$. 5-HMF was inactive since its $\mathrm{IC}_{50}>2.0 \mathrm{mg} / \mathrm{mL}$. Data are expressed as mean of three measurements of triplicate tests \pm standard deviation.<smiles>O=Cc1ccc(CO)o1</smiles>

1<smiles>Cc1ccc(C=O)o1</smiles>

6<smiles>OCc1cocc1CO</smiles>

11<smiles>COC(=O)c1ccco1</smiles>

2<smiles>CC1=CCC(=O)O1</smiles>

7<smiles>CC1C=CC(=O)O1</smiles>

12<smiles>O=Cc1ccco1</smiles>

3<smiles>OCc1ccco1</smiles>

8<smiles>CC1=C(O)C(=O)C(C)(O)O1</smiles>

13<smiles>CC1=C(O)C(=O)C(O)CO1</smiles>

4<smiles>Cc1ccoc1C(=O)O</smiles>

9<smiles>O=Cc1ccc(C=O)o1</smiles>

14<smiles>CC(=O)c1ccco1</smiles>

5<smiles>Cc1cc(=O)c(O)co1</smiles>

16<smiles>O=Cc1ccc(Cc2ccco2)o1</smiles>

17<smiles>Cc1ccc(Cc2ccc(C=O)o2)o1</smiles>

18

Figure 5. Structures of flavor compounds identified by GC-MS.
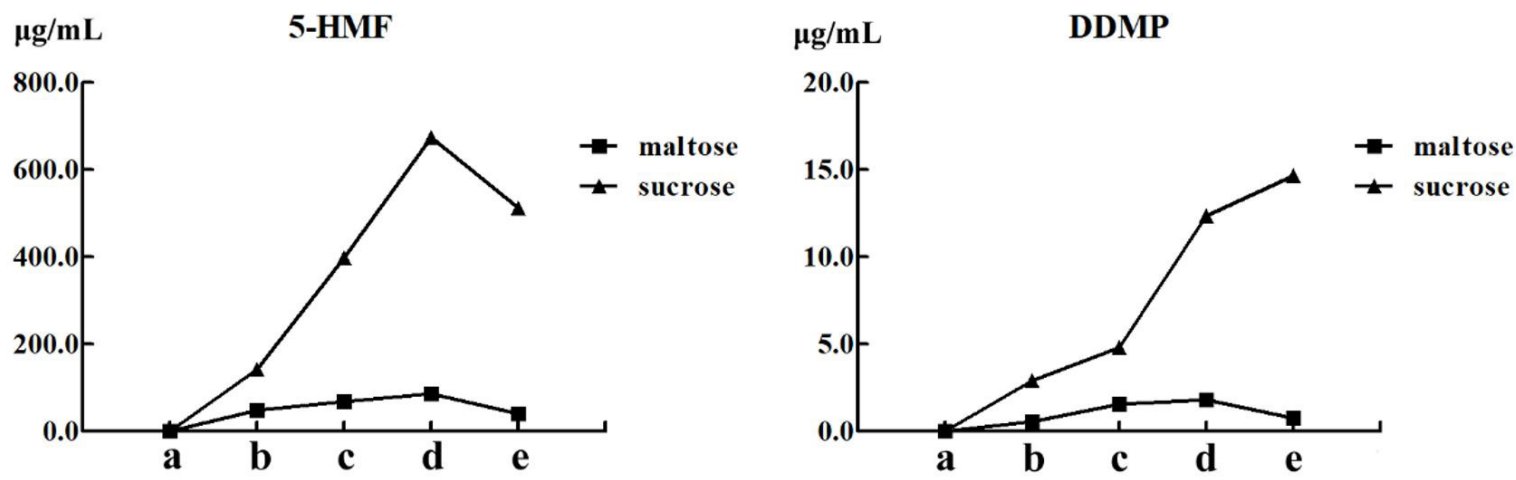

Figure 6. Concentrations of 5-HMF and DDMP in MCPs and SCPs. 


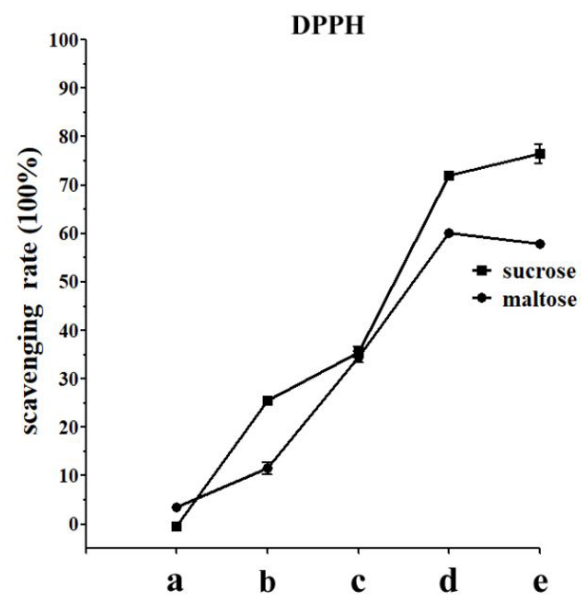

Figure 7. Radical scavenging effects of MCPs and SCPs at $1.0 \mathrm{mg} / \mathrm{mL}$.

\section{Conclusion}

The results showed that a suggested condition for both maltose and sucrose caramel reactions was proposed at $180^{\circ} \mathrm{C}$ for $4 \mathrm{~min}$. And sucrose caramels exhibited better reaction rates, colors, flavors, and antioxidant effects than those of maltose caramels. Based on their characteristic flavors, antioxidant activities, and safeties, these caramels are promising in the application of food industry.

\section{Acknowledgements}

This research work was funded by the Technical Program of China Tobacco Sichuan Industrial Co., Ltd. [hx201908] and the Key Scientific Research Projects of Higher Education Institutions of Henan Province [20A350020].

\section{References}

Chappel, C. I., \& Howell, J. C. (1992). Caramel colours: a historical introduction. Food and Chemical Toxicology, 30(5), 351-357. http:// dx.doi.org/10.1016/0278-6915(92)90060-X. PMid:1644375.

Cunha, S. C., Barrado, A. I., Faria, M. A., \& Fernandes, J. O. (2011). Assessment of 4-(5)-methylimidazole in soft drinks and dark beer. Journal of Food Composition and Analysis, 24(4-5), 609-614. http:// dx.doi.org/10.1016/j.jfca.2010.08.009.

Geng, Y. C., Ning, Y. L., Shao, Q., Lv, Y. Z., Wei, X. F., Dai, Y. J., Jia, S. R., Zhong, C., Man, S. L., Zhang, L. M., \& Zhang, X. L. (2019). Preparation and characterization of acylcaramel. Journal of Agricultural and Food Chemistry, 67(19), 5614-5620. http://dx.doi.org/10.1021/ acs.jafc.8b07148. PMid:31017780.

Golon, A., \& Kuhnert, N. (2012). Unraveling the chemical composition of caramel. Journal of Agricultural and Food Chemistry, 60(12), 3266-3274. http://dx.doi.org/10.1021/jf204807z. PMid:22375847.

Golon, A., \& Kuhnert, N. (2013). Characterisation of "caramel-type" thermal decomposition products of selected monosaccharides including fructose, mannose, galactose, arabinose and ribose by advanced electrospray ionization mass spectrometry methods. Food

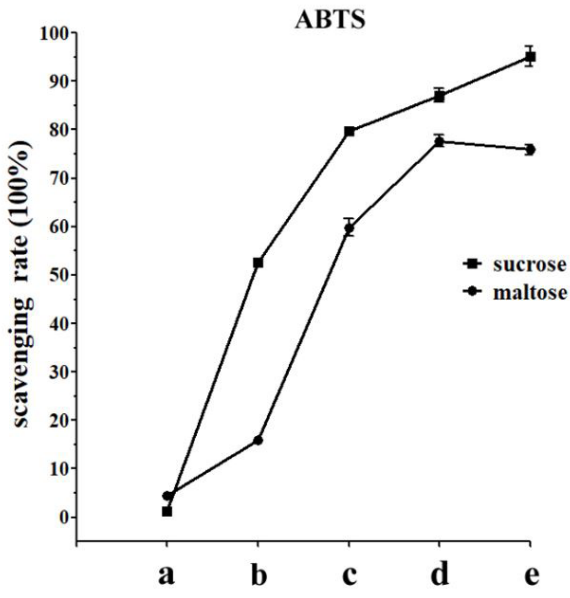

\& Function, 4(7), 1040-1050. http://dx.doi.org/10.1039/c3fo30352g. PMid:23529212.

Klejdus, B., Moravcová, J., Lojková, L., Vacek, J., \& Kubáň, V. (2006). Solid-phase extraction of 4(5)-methylimidazole (4MeI) and 2-acetyl4(5)-(1,2,3,4-tetrahydroxybutyl)-imidazole (THI) from foods and beverages with subsequent liquid chromatographic-electrospray mass spectrometric quantification. Journal of Separation Science, 29(3), 378-384. http://dx.doi.org/10.1002/jssc.200500421. PMid:16544879.

Li, T. X., Meng, D. D., Guo, Y. X., Bai, B., Xu, G. G., Yang, Y. N., Xie, X. Y., Wang, Y., \& Xu, C. P. (2020). Antioxidant epoxydon and benzolactone derivatives from the insect-associated fungus Phoma sp. Journal of Asian Natural Products Research, 22(7), 647-654. http://dx.doi.org /10.1080/10286020.2019.1612380. PMid:31120358.

Moon, J. K., \& Shibamoto, T. (2011). Formation of carcinogenic 4(5)-methylimidazole in Maillard reaction systems. Journal of Agricultural and Food Chemistry, 59(2), 615-618. http://dx.doi. org/10.1021/jf104098a. PMid:21186780.

Pons, I., Garrault, C., Jaubert, J. N., Morel, J., \& Fenyo, J. C. (1991). Analysis of aromatic caramel. Food Chemistry, 39(3), 311-320. http://dx.doi.org/10.1016/0308-8146(91)90148-H.

Thomas, M. J., \& Bielski, B. H. J. (1989). Oxidation and reaction of trolox c, a tocopherol analog, in aqueous solution. a pulse-radiolysis study. Journal of the American Chemical Society, 111(9), 3315-3319. http://dx.doi.org/10.1021/ja00191a031.

Uríčková, V., \& Sádecká, J. (2015). Determination of geographical origin of alcoholic beverages using ultraviolet, visible and infrared spectroscopy: a review. Spectrochimica Acta. Part A: Molecular and Biomolecular Spectroscopy, 148, 131-137. http://dx.doi.org/10.1016/j. saa.2015.03.111. PMid:25879982.

Yoshiki, Y., \& Okubo, K. (1995). Active oxygen scavenging activity of DDMP (2,3-dihydro-2,5-dihydroxy-6-methyl-4H-pyran-4-one) saponin in soybean seed. Bioscience, Biotechnology, and Biochemistry, 59(8), 1556-1557. http://dx.doi.org/10.1271/bbb.59.1556.

Yu, X. Y., Zhao, M., Liu, F., Zeng, S. T., \& Hu, J. (2013). Identification of 2,3-dihydro-3,5-dihydroxy-6-methyl-4H-pyran-4-one as a strong antioxidant in glucose-histidine Maillard reaction products. Food Research International, 51(1), 397-403. http://dx.doi.org/10.1016/j. foodres.2012.12.044. 